\title{
Peningkatan Hasil Belajar Siswa Pada Keterampilan Menulis Muatan Pelajaran Bahasa Indonesia Menggunakan Media Pembelajaran Kartu Kilas (Flash Cards)
}

\author{
Ami Sulistiyowati \\ SD Negeri Banjaranyar 01 \\ amisulistiyowati1303@gmail.com
}

\section{Article History}

received 3/12/2020

revised 17/12/2020

accepted 31/12/2020

\begin{abstract}
The aim of this research is to determine the improvement of students "learning outcomes in writing skill of indonesian by using flash cards media. The research conducted was a Classroom Action Research (PTK) with three cycles consisting of two meetings. Each meeting is carried out a pre test and post test. The subjects of this study were grade I SD Negeri Banjaranyar 01 which consisted of 24 students. KKM standard 65 out of 24 students only 11 students or $45.8 \%$ who reached a value of 65 and above while 13 students or $54.2 \%$ got a score below KKM. The results showed that the improvement of students"learning outcomes in writing skills of Indonesian. In the pre-cycle obtained an average score of the $45.8 \%$. Then increased in first cycle with a score of $58.3 \%$, increased back in the second cycle $87.5 \%$. These results indicated that using flash cards can improved the sudents"learning outcomes in writing skills of Indonesian especially grade I at SD Negeri Banjaranyar 01 Brebes.
\end{abstract}

Keywords: learning outcomes, writing skills, flash cards

\begin{abstract}
Abstrak
Abstrak dalam bahasa Indonesia mengikuti kaidah dalam Pedoman Umum Ejaan Bahasa Indonesia (PUEBI)Tujuan penelitian ini adalah untuk mengetahui peningkatan hasil belajar siswa pada keterampilan menulis Bahasa indonesia menggunakan media kartu kilas.Penelitian yang dilakukan adalah Penelitian Tindakan Kelas dengan tiga siklus dimana setiap siklusnya terdiri atas dua pertemuan. Masing-masing pertemuan terdiri atas pre tes dan post test.Subyek penelitian ini aadalah kelas I SD Negeri Banjaranyar 01 dimana terdiri atas 24 siswa. Standar KKM 67 dari 24 siswa hanya 11 siswa atau 45,8\% yang mencapai nilai 67 keatas sedangkan 13 siswa atau $54,2 \%$ mendapat nilai di bawah KKM. Hasil penelitian menunjukan adanya peningkatan hasil belajar siswa pada keterampilan menulis muatan pelajaran Bahasa indonesia. Di pra siklus memperoleh nilai $45,8 \%$. Kemudian di siklus pertama mengalami peningkatan nilai $58,3 \%$, meningkat pada siklus kedua $87,5 \%$. Hasil penelitian ini menunjukkan penggunaan media kartu kilas dapat meningkatkan hasil belajar siswa pada keterampilan menulis muatan pelajaran Bahasa Indonesia khususnya kelas I di SD Negeri Banjaranyar 01 Brebes.
\end{abstract}

Kata kunci: hasil belajar, keterampilan menulis, kartu kilas

Social, Humanities, and Education Studies (SHEs): Conference Series https://jurnal.uns.ac.id/shes

p-ISSN 2620-9284

e-ISSN 2620-9292 


\section{PENDAHULUAN}

Dari perolehan nilai hasil belajar dapat terlihat tercapainya indikator pembelajaran yang berkualitas. Nilai hasil belajar dapat ditingkatkan apabila pembelajaran berlangsung dengan efektif dan efisien. Juga adanya sarana dan prasarana yang menunjang selain kemampuan guru dalam mengajar. Untuk meningkatkan hasil pembelajar alangkah baiknya guru menggunakan media pembelajaran dalam kegiatan belajar mengajar. Dengan adanya media pembelajaran akan menarik minat siswa untuk lebih memperhatikan pelajaran yang diberikan dan hal itu akan berpengaruh pada peningkatan hasil belajar siswa.

Kurikulum 2013 memiliki empat aspek penilaian yaitu aspek pengetahuan, aspek keterampilan, aspek sikap dan aspek perilaku/ moral. Pada pembelajaran yang digunakan oleh K13 yaitu menggunakan tema, yang didalamnya terdapat beberapa muatan pelajaran. Disini penulis akan memaparkan muatan pelajaran bahasa Indonesia. Muatan pelajaran bahasa Indonesia terdiri dari empat keterampilan yaitu keterampilan menyimak, berbicara, membaca dan menulis. Keterampilan menyimak merupakan keterampilan awal ketika anak mulai belajar bahasa. Dengan menyimak, anak-anak belajar bahasa lisan mereka dengan berulang-ulang. Keterampilan berbicara merupakan keterampilan lisan, dimana mereka belajar untuk mengungkapkan pendapat, pikiran dan perasaannya. Keterampilan membaca dan menulis merupakan keterampilan terpadu. Dari keempat keterampilan diatas, keterampilan yang utama dibutuhkan anak kelas satu sebagai dasar adalah membaca dan menulis.

Menurut Heinich yang dikutip oleh azhar Arsyad (2011:4), media pembelajaran adalah perantara yang membawa pesan atau informasi bertujuan instruksional atau mengandung maksud-maksud pengajaran antara sumber dan penerima.

Kartu kilas atau flash cards biasanya berisi tulisan atau gambar yang ditunjukkan secara cepat sehingga siswa tertarik untuk memperhatikan. Kartu kilas digunakan untuk seluruh kelas sehingga

Berdasarkan pengalaman peneliti pada kelas I SD Negeri Banjaranyar 01 khususnya pada muatan pelajaran bahasa Indonesia ditemui permasalahan salah satunya kurangnya minat siswa mengikuti pembelajaran sehingga mempengaruhi hasil belajarnya.

Ditinjau dari masalah yang ditemui tersebut penulis berkeyakinan bahwa penggunaan media pembelajaran sangat diperlukan untuk meningkatkan hasil belajar siswa. Dalam hal ini media pembelajaran yang akan digunakan adalah kartu kilas /flash cards. Berdasarkan identifikasi masalah diatas penulis mengambil judul Peningkatan Hasil Belajar Siswa Pada Kemampuan Menulis Muatan Pelajaran Bahasa Indonesia menggunakan media Pembelajaran Kartu Kilas.

\section{METODE}

Jenis penelitian yang digunakan adalah Penelitian Tindakan Kelas. Penelitian dilakukan di SD Negeri Banjaranyar 01 Kecamatan brebes, Kabupaten Brebes, Provinsi Jawa Tengah pada semester ganjil bulan Juli- agustus. Subyek penelitian ini adalah 24 siswa kelas I SD Negeri banjaranyar 01 Brebes. Adapun penelitian dilakukan sebanyak dua siklus dimana masing-masing siklus ada dua kali pertemuan. Prosedur yang dilakukan pada Penelitian Tindakan kelas ini yaitu 1). Refleksi awal, 2). Menyusun perencanaan , 3). Pelaksanaan tindakan,4). Observasi, 5) refleksi. 


\section{HASIL DAN PEMBAHASAN}

A. Deskripsi hasil penelitian Tindakan Kelas.

Penulis melakukan Penelitian Tindakan kelas sebanyak dua siklus. Hasil perbaikan pada masing-masing siklus mencakup penilaian perbaikan dan hasil belajar siswa.

1. Pra siklus

a. Hasil pengolahan data

Untuk mengetahui perolehan nilai hasil belajar, maka diadakan tes formatf. Hasil belajar siswa dalam pembelajaran3 tema 6 (lingkungan Bersih Sehat dan Asri) subtema 2 (Lingkungan Sekitar Rumahku) muatan pelajaran Bahasa indonesia dicantumkan dalam tabel berikut :

Tabel 1. Data Hasil Belajar Siswa Pra Siklus

\begin{tabular}{cccc}
\hline No. & Nilai & \multicolumn{2}{c}{ Pra Siklus } \\
\hline 1. & 20 & Frekuensi (x) & Fx \\
2. & 30 & 0 & 40 \\
3. & 40 & 2 & 0 \\
4. & 50 & 4 & 80 \\
5. & 60 & 5 & 200 \\
6. & 70 & 6 & 300 \\
7. & 80 & 3 & 420 \\
8. & 90 & 2 & 240 \\
9. & 100 & & 180 \\
\multicolumn{4}{r}{} \\
Nilai Rata-rata & 24 & 0 \\
\end{tabular}

a. Deskripsi Temuan

Setelah dilakukan analisis dan refleksi terhadap perolehan hasil belajar pra siklus, diketahui bahwa :

$>$ Guru masih lupa menyampaikan tujuan pembelajaran yang telah direncanakan untuk disampaikan pada awal pembelajaran

> Jawaban atas pertanyaan yang diberikan ke siswa, masih di dominan oleh siswa pintar saja

$>$ Siswa masih kurang memperhatikan guru saat guru sedang menjelaskan

$>$ Media yang digunakan belum mampu menarik perhatian siswa

$>$ Metode yang digunakan belum tepat

$>$ Nilai rata-rata formatif siswa masih dibawah KKM 60,83

Dari nilai tes formatif pra siklus pada muatan pelajaran bahasa Indonesia tema 6 " Lingkungan Bersih Sehat dan Asri" subtema 2 "Lingkungan Sekitar Rumahku" pembelajaran 3, diketahui bahwa siswa yang telah mencapai ketuntasan baru 11 siswa ( 45,8\%) dan yang belum mencapai ketuntasan yakni 13 siswa (54,2\%) dari 24 siswa, sehingga perlu dilakukan Penelitian Tindakan Kelas (PTK) melalui perbaikan pembelajaran pada siklus selanjutnya yaitu siklus $\mathrm{I}$. 


\section{Siklus I}

a. Hasil Pengolahan Data

Berikut ini penulis sajikan data kualitas pelaksanaan aktivitas perbaikan pembelajaran muatan pelajaran bahasa Indonesia siklus I. Kemajuan aktivitas perbaikan pembelajaran dapat dilihat pada table dibawah ini :

Tabel 2. Data Hasil Belajar Siswa Siklus I

\begin{tabular}{|c|c|c|c|}
\hline \multirow{2}{*}{ No. } & \multirow{2}{*}{ Nilai } & \multicolumn{2}{|c|}{ Pra Siklus } \\
\hline & & Frekuensi (x) & $\mathbf{F x}$ \\
\hline 1. & 20 & 2 & 40 \\
\hline 2. & 30 & 0 & 0 \\
\hline 3. & 40 & 1 & 40 \\
\hline 4. & 50 & 5 & 250 \\
\hline 5. & 60 & 2 & 120 \\
\hline 6. & 70 & 4 & 280 \\
\hline 7. & 80 & 6 & 480 \\
\hline 8. & 90 & 4 & 360 \\
\hline 9. & 100 & & 0 \\
\hline \multicolumn{2}{|c|}{ Jumlah } & 24 & 1670 \\
\hline \multicolumn{2}{|c|}{ Nilai Rata-rata } & - & 65,42 \\
\hline
\end{tabular}

a. Deskripsi Temuan

Setelah dilakukan analisis dan refleksi terhadap perolehan hasil perbaikan pada siklus I, diketahui bahwa :

> Pemberian apersepsi yang menarik. Guru memancing respon dengan mengajukan pertanyaan tentang $L$ ingkungan disekitar Rumahku.

> Pengaktifan siswa dalam Tanya jawab. Ketika proses KBM berlangsung, siswa diberi pertanyaan untuk mengerjakan soal di papan tulis. Walaupun belum maksimal, siswa tetap semangat mengerjakan soal.

$>$ Pemanfaatan alat peraga. Guru sudah menyediakan alat peraga sesuai dengan materi yang diajarkan. Guru menunjukan kartu kilas berupa gambar, siswa menjawab gambar yang ada pada kartu kilas, kemudian menuliskan kata yang sesuai dengan gambar.

$>$ Nilai rata-rata formatif siswa masih dibawah KKM 67

Dari nilai tes formatif siklus I pada muatan pelajaran bahasa Indonesia tema 6 "Lingkungan Bersih Sehat dan Asri" subtema 2 "Lingkungan Sekitar Rumahku" pembelajaran 3, diketahui bahwa siswa yang telah mencapai ketuntasan baru 14 siswa ( $58,3 \%$ ) dan yang belum mencapai ketuntasan yakni 10 siswa ( $41,7 \%)$ dari 24 siswa, sehingga perlu dilakukan Penelitian Tindakan Kelas (PTK) melalui perbaikan pembelajaran pada siklus selanjutnya yaitu siklus II. 


\section{Siklus II}

a. Hasil Pengolahan Data

Berikut ini penulis sajikan data kualitas pelaksanaan aktivitas perbaikan pembelajaran muatan pelajaran bahasa Indonesia siklus II. Kemajuan aktivitas perbaikan pembelajaran dapat dilihat pada table dibawah ini :

Tabel 3. Data Hasil Belajar Siswa Siklus II

\begin{tabular}{cccc}
\hline No. & Nilai & \multicolumn{2}{c}{ Pra Siklus } \\
\hline 1. & 20 & Frekuensi $(\mathbf{x})$ & Fx \\
2. & 30 & 0 & 0 \\
3. & 40 & 0 & 0 \\
4. & 50 & 2 & 0 \\
5. & 60 & 1 & 100 \\
6. & 70 & 4 & 60 \\
7. & 80 & 6 & 280 \\
8. & 90 & 8 & 480 \\
9. & 100 & 3 & 720 \\
& Jumlah & 24 & 300 \\
& Nilai Rata-rata & - & 80,83 \\
\hline
\end{tabular}

b. Deskripsi Temuan

Setelah dilakukan analisis dan refleksi terhadap perolehan hasil perbaikan pada siklus II, diketahui bahwa :

$>$ Pemberian apersepsi yang menarik.

$>$ Pengaktifan siswa dalam Tanya jawab. Ketika proses KBM berlangsung perlu dilakukan.

$>$ Pemanfaatan alat peraga.

$>$ Nilai rata-rata formatif siswa sudah mencapai KKM 80,83.

Dari data kualitas pelaksanaan penelitian tindakan kelas dan hasil tes formatif peserta didik di kelas 1 SD Negeri Banjaranyar 01 Brebes dapat dikatakan bahwa pelaksanaan penelitian tindakan kelas rata-rata meningkat. Peningkatan prestasi belajar peserta didik terjadi karena dalam penelitian tindakan kelas secara konsekuen penulis melakukan aktivitas-aktivitas pembelajaran yang meliputi:

1. Keaktifan peserta didik dalam tanya jawab

Tanya jawab adalah cara penyajian pelajaran dalam bentuk pertanyaan yang harus dijawab terutama dari guru kepada siswa tetapi dapat pula dari siswa kepada guru.

2. Pemberian penjelasan

Cara guru dalam usaha untuk menyampaikan pengetahuan dan informasi kepada peserta didik yang mudah dipahami dan dimengerti dengan jelas oleh semua peserta didik.

3. Pemanfaatan media pembelajaran 
Media pembelajaran merupakan salah satu jalan untuk memudahkan seorang guru dalam melaksanakan tugasnya untuk mencapai tujuan pembelajaran.

4. Pengaktifan peserta didik dalam latihan soal

Pemberian latihan soal-soal dimaksudkan memberikan kesempatan pada peserta didik untuk melaksanakan tugas dan mengukur kemampuan peserta didik.

5. Pemberian soal evaluasi

Dalam proses belajar mengajar yang melakukan evaluasi adalah guru yang merencanakan dan melaksanakan kegiatan belajar mengajar. Guru sebagai sumber informasi yang selalu berinteraksi dengan anak didik memerlukan evaluasi secara teratur agar dapat memperbaiki atau menyempurnakan proses belajar mengajar.

Tujuan evaluasi adalah memberi informasi yang berkaitan dengan kemampuan peserta didik,pembinaan kegiatan belajar,menerapkan kemampuan dalam kesulitan,mendorong motivasi belajar.

Perbaikan pembelajaran yang dilakukan peneliti menunjukan adanya peningkatan kemampuan guru (peneliti) dan hasil evaluasi siswa. Hasil evaluasi siswa mengalami peningkatan setelah dilaksanakan perbaikan pembelajaran. Pada kegiatan pra siklus menunjukan nilai awal yang mendorong peneliti untuk mengadakan penelitian. Dari pra siklus ke siklus I kemudian siklus II mengalami perubahan nilai yang cukup signifikan dan ketuntasan siswa yang semakin meningkat yakni dari $45,8 \%$ (pra siklus) menjadi $58,3 \%$ (siklus I) dan $87,5 \%$ (siklus II).

\section{SIMPULAN}

Berdasarkan hasil analisis data dan pembahasan penelitian sampai siklus II dapat dikemukakan simpulan sebagai berikut :

Bahwa penerapan media kartu kilas/ flash cards dapat digunakan untuk meningkatkan ketrampilan menulis siswa kelas 1 SD Negeri Banjaranyar 01 Kecamatan Brebes Kabupaten Brebes. Hal ini terbukti adanya peningkatan hasil belajar siswa. Meningkatnya nilai rata-rata yang diperoleh siswa sebelum dilakukan tindakan (T-0)/ pra siklus 60,83; tindakan pertama (T-1)/ siklus I 65,42; dan tindakan kedua (T-2)/ siklus II 80,83 .

Dari angka tersebut diatas dapat dikatakan bahwa ada peningkatan hasil belajar yang baik dilihat dari hasil tes sebelum tindakan hingga hasil akhir setelah diberi tindakan/ perbaikan.

\section{DAFTAR PUSTAKA}

Arsyad, Azhar.2011. Media Pembelajaran. Jakarta: PT. Raja Grafindo Persada. Arikunto, Suharsimi. 2020. Penelitian Tindakan Kelas. Jakarta: Bumi Aksara.

Aqib, zainal. 2011. Penelitian Tindakan Kelas. Bandung: Yrama Widya

Dahar, Ratna wilis.2011.Teori Belajar dan Pembelajaran. Jakarta:Erlangga.

Hamdani. 2011. Strategi Belajar Mengajar. Bandung: Pustaka Setia.

Jihad, A. 2014. \& Haris, A. 2016. Evaluasi Belajar.Yogyakarta: Multi Pressindo.

TW.Solchan. 2014. Materi Pokok Pendidikan bahasa Indonesia di SD. Tangerang Selatan: Universitas Terbuka.

Winarsunu, T. 2017. Statistik dalam Penelitian Psikologi dan Pendidikan. Malang: UMM Pres. 